\title{
A new framework to analyse workforce contribution to Australian cotton farm adaptability
}

\author{
Ruth Nettle ${ }^{1}$ (D) $\cdot$ Geoff Kuehne ${ }^{1} \cdot$ Kate Lee $^{2} \cdot{\text { Dan } \text { Armstrong }^{3}}^{3}$
}

Accepted: 7 June 2018 / Published online: 9 July 2018

(C) The Author(s) 2018

\begin{abstract}
Farmers face many challenges, including climate variability, that require continual adaptation. However, studies of farm adaptation have paid limited attention to the farm workforce, despite changes in farm workforce organisation (i.e. the number, type and forms of employment on farm) being a significant feature of agricultural change globally. To effectively support farmers' adaptation, it is important to understand farmers' workforce strategies (i.e. how farm workforce organisation supports the needs and priorities of the farm), how workforce choices are made and the implications for adaptation. This paper progresses a framework for analysing farm adaptability, including the farm workforce. Bringing together theories of livelihoods analysis and strategic human resource management, the farm workforce strategies of 16 case study farms in the Australian cotton production sector are analysed. Cotton production is exposed to major resource constraints, such as irrigation water. We interviewed farmers and collected data on farm business performance, workforce organisation choices, human resource management practices and employees' experiences of work. We integrated data to characterise farm workforce decision-making and the relationship between workforce strategies and farm adaptability for each farm. A cross-case analysis explored differences between farms. A diversity of workforce strategies was found, involving combinations of workforce options, defined as 'core', 'contract' and 'casual' workers at different levels of skills and experience. Farm workforce strategies were found to influence and be influenced by sources of financial capital, irrigation water availability/holdings, farm remoteness, new farm infrastructure and human resource management practices. The farm workforce was a response option to provide production flexibility, yet high adaptability was associated with some negative consequences for managers and employees. We show for the first time the influence of farm workforce organisation dynamics in adaptation and negative consequences of high farm adaptability. 'Factoring-in' the farm workforce in sustainable development studies should therefore be a priority.
\end{abstract}

Keywords Workforce organisation $\cdot$ Decision-making $\cdot$ Strategic human resource management

This work was completed when Kate Lee was in the Rural Innovation Research Group, Faculty of Veterinary and Agricultural Sciences, Melbourne, Australia

Ruth Nettle

ranettle@unimelb.edu.au

Geoff Kuehne

geoffkuehne@gmail.com

Kate Lee

kate.lee@unimelb.edu.au

Dan Armstrong

armstrongdan@bigpond.com

1 Rural Innovation Research Group, Faculty of Veterinary and Agricultural Sciences, University of Melbourne, Melbourne, Australia

2 Faculty of Science, University of Melbourne, Melbourne, Australia

3 D-Arm consulting, Melbourne, Australia

\section{Introduction}

As with many nations, a key challenge for Australian agricultural producers is to continually innovate and adapt in the context of a global economy, technological advances and a more variable climate (Marshall et al. 2014). This has increased interest among agricultural systems and sustainability scientists in the ways farming systems are changing, farmers' adaptability and the analysis of production and management options that support adaptability (Darnhofer et al. 2010). Adaptability has been described as a 'decision-making process and the set of actions undertaken to maintain the capacity to deal with current or future predicted change' (Nelson et al. 2007, p. 396). It includes the ability of people to mobilise resources; the management of risk and uncertainty; skills in planning, learning and reorganising; financial and emotional flexibility; and an 
interest in adapting (Marshall et al. 2013). Studies of farmer adaptability often focus on the farm owner/decisionmaker and the production systems and sub-systems changes they implement. The social organisation or reorganisation of farming systems has not featured strongly in these studies.

Whilst human and social capital are included in indicators of adaptability, they have largely concerned farm owner attributes such as education levels and management skills or labour supply metrics (Ellis 2000; Marshall 2010) rather than including all the human resources involved in farming. The human resources involved in farming include farm owners and managers, sharefarmers, contributing family workers, employees (farm labour) and contractors. In this paper, the term 'farm workforce' relates to all these human resource categories reflecting broader changes in the social organisation of farming in developed countries (Lobley and Potter 2004; Santhanam-Martin and Nettle 2015). In a recent review of processes of adaptation within farm decision-making models, workforce resource decisions were absent from models relating to converting cash crops to silage for livestock feed in drought conditions (Robert et al. 2016). In a study of peanut growers making transformational changes in Australia, Marshall et al. (2014) discussed farmers' capacity to be employed outside the farm as an adaptation strategy, but did not consider the farm workforce decisions and implications associated with other adaptation strategies, such as changing farm location or the difficulties accessing a workforce in a more remote location (McKenzie 2011). The role of the farm workforce in adaptability remains largely invisible, despite the limited availability of a farm workforce increasing the importance of work organisation in many countries (Darnhofer et al. 2010).

Farm workforce organisation takes place within a broader context of social trends and expectations of work and working life. A recent OECD employment outlook considers the number and quality of jobs, inclusiveness and diversity of the workforce, and resilience and adaptability as crucial for economic growth and well-being (OECD 2017). Trends such as an increasing pace of change, uptake in technology and globalisation are affecting the workforce and disproportionately affecting 'midskill/mid-pay workers', such as those in manufacturing (ibid: p.18). Even when workers' skills are matched with their jobs, outcomes for individuals and organisations can be affected by other workplace factors. For example, practices such as restructuring, layoffs, work instability, reduced work entitlements, unsupportive work environments and limited control over job/working life can have extremely detrimental effects. These include lower productivity, poorer physical and mental health and well-being impacts (Pfeffer 2010).

Change in farm workforce organisation in the past decade has been a significant feature of the agricultural environment.
In Australia, this has involved reduction in the family workforce as a proportion of the total farm workforce, more reliance on hired farm labour and an increase in casual (temporary), contractor and seasonal workforces, including from overseas (Bahn 2014; Nettle 2015). The trends are largely attributed to increased labour productivity, increased farm size shifting the structure of farm production, the substitution of capital for labour (i.e. labour-saving technologies) and broader demographic and social changes related to farm family members, such as their interest in remaining in, or returning to, farming (Santhanam-Martin and Nettle 2014). More recent changes have been linked to the need for flexibility, given the dynamic nature of agricultural production in terms of seasonal variation, drought, resource availability, product price variations from year to year and in response to large-scale regional labour market trends, for example the impact of the recent mining boom in Australia on regional workforces (Nettle 2015).

Whilst family farming makes up $97 \%$ of all farms in Australia, increasing farm size has meant some farm families are implementing corporate work organisation models, where ownership and management are separated, and farm managers and farm management teams may not involve family members. It has been suggested by rural sociologists in Australia that such farmers represent a new category of farming - that of 'farm family entrepreneurs' (Pritchard et al. 2007, p. 75) where family units remain at the social and economic heart of farm ownership and operation, but relate to assets through legal and financial structures characteristic of the wider economy (ibid: p. 75). In this regard, 'farm business' in Australia is broadly considered to include those family farms in which a great part of the owner or manager family is involved in work, without any limitation concerning farm size or number of employees (97\%), and corporate farms (3\%) where ownership and management are separate. The diversity in farm workforce structures and work organisation (i.e. the distribution and coordination of work tasks, skills and authority) has also affected the way farmers engage in labour markets and consider decisions related to the following: family member roles, which workforce strategies to choose (e.g. the use of contractors, hiring experienced managers or utilising seasonal worker schemes), and methods to best recruit, select and manage employees. Many of these changes have been reported in both developing and developed agricultural economies (Errington and Gasson 1996; Findeis et al. 2002; Dedieu 2009).

It is pertinent to consider why these changes have not featured more strongly in studies of farm adaptation or the implications for sustainable development pathways. This could be due to the general difficulty in measuring human resources and the nature of the workplace environment, such as job quality or work conditions (Harrison and Getz 2015), the difficulty in modelling workforce dynamics in farming systems (Robert et al. 2016) or in incorporating the influence of 
external factors, such as labour market conditions, and the entry or exit of people in farming (Santhanam-Martin and Nettle 2014). However, on further analysis, it would appear that the farm workforce is examined only as a cost (e.g. Nelson et al. 2010; Rasmussen et al. 2017) and a source of vulnerability for farm adaptation, leaving little scope for consideration of the farm workforce as a source of flexibility and advantage for adaptability. Understanding the nature of farm workforce decisions and the dynamics of workforce organisation is important in developing methods to better account for human resources in farming system adaptability. Farming system researchers have recognised this issue, with calls to better understand farming as complex adaptive systems, 'how they morph' and how trade-offs between efficiency and adaptability are managed (Schiere et al. 2012: 357).

This paper addresses some of these oversights by examining the cotton production sector in Australia, which faces substantial challenges related to climate variability, water policy reforms, shifts in technology and competition for skilled workforces (visually represented in Fig. 1). The paper aims to understand how farm workforce organisation supports the needs and priorities of farms faced with challenges, how workforce strategies are chosen and the implications of different strategies for adaptability. The paper advances a new approach for analysing farm adaptability to identify potential vulnerabilities and sources of resilience in farming systems related to the farm workforce.

\section{Materials and methods}

\subsection{Choice and description of case study}

\subsubsection{Australian cotton farming}

Agricultural production is a significant contributor to the Australian economy. Farm production valued at $\$ 51$ billion
(2013-2014) contributed 2\% of Australia's gross domestic product (GDP) and $15 \%$ of the total merchandise exports (Commonwealth of Australia 2015: 4). Whilst the percentage of the population employed in farming has declined to $2 \%$ over the past 50 years, agriculture remains a significant employer in regional (non-city) areas, with 270,000 people employed in production (ABARES 2015). Government reforms related to irrigation water access (Australian Government 2012) combined with a drying climate represent a major challenge for farmers (CSIRO and Bureau of Meteorology 2015).

The cotton production sector in Australia can be broadly classified as a conventional farming system within a commodity socioeconomic framework (Therond et al. 2017). The sector is considered to have high levels of technical efficiency, having improved water use efficiency by $40 \%$ in two decades (Roth et al. 2014) and achieved some of the world's highest average yields, averaging over 7.5 bales to the hectare (Cotton Australia 2016). These efficiencies have been achieved whilst there have been large fluctuations in the areas planted due in part to a variable water supply (Cotton Australia 2016, de Garis 2013) (Fig. 2). The major part of the Australian cotton crop is grown using flood irrigation (Fig. 1). Other mechanised forms of irrigation are being adopted, and these also reduce the need for labour but increase the need for a skilled workforce (Raine and Foley 2002). The introduction of new round bale cotton pickers in 2009 (Fig. 1) (Woodhouse et al. 2013), and their rapid adoption to over $90 \%$ of harvesters by 2016 , has reduced labour requirements, but increased the need for skills such as computer literacy and machinery management to avoid soil compaction (de Vetten 2014).

Cotton production areas are close to areas of minerals exploration and mining, creating competition for machinery operators with cotton farms reporting workforce shortages of $20-40 \%$ of the required total workforce through the years 2010-2014 (Moffatt et al. 2013; Nettle 2015). This led to an increase in the use of temporary workforces, such as contract
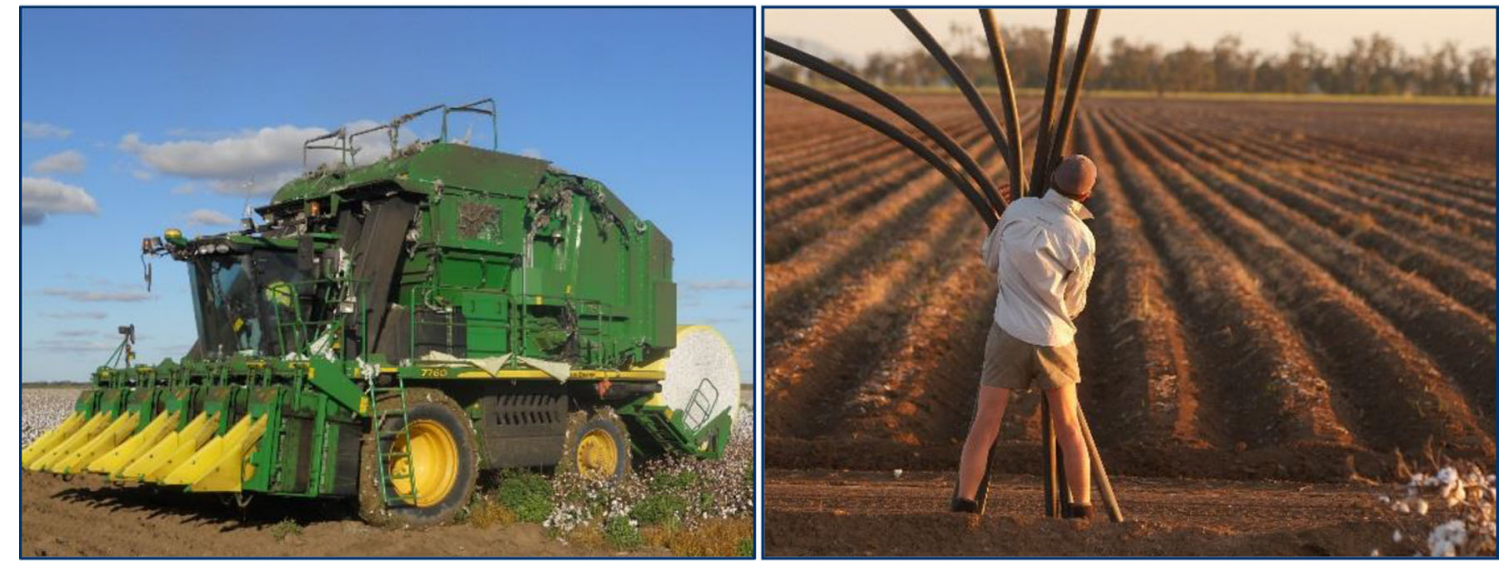

Fig. 1 Cotton farmers' workforce strategies inter-relate with technology investment (e.g. round bale pickers, on left), irrigation water availability and workforce availability (e.g. working with irrigation siphons, on right). The farm workforce plays an important role in adaptability in the farming system 


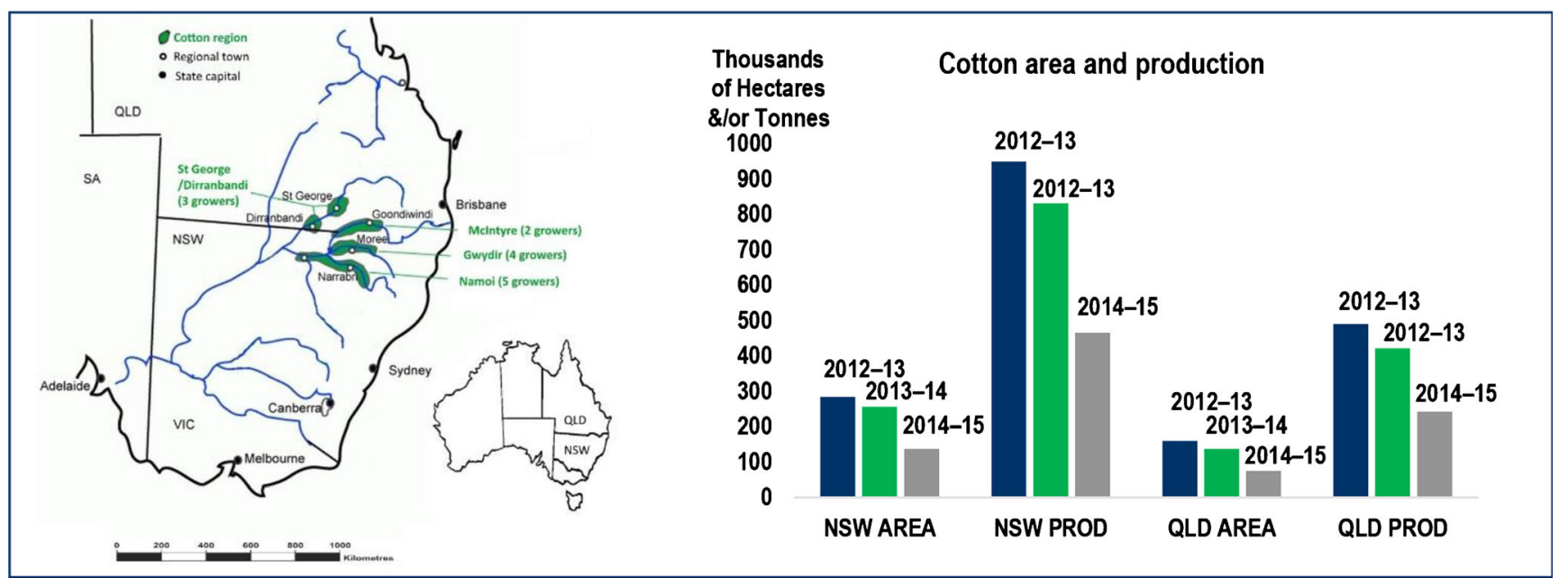

Fig. 2 Location of case study farms involved in this study and the annual variation in area of production under cotton and yields by state (NSW, Queensland) 2012-2015 (Cotton Australia 2016); note two farms from

labour and seasonal workers, including 'grey nomads' (semiretired Australians travelling around the country who pick up temporary work) and working holiday visa holders or 'backpackers' from overseas. There is also increased reliance on skilled migration schemes (Bahn 2014; Australian Government 2017).

Cotton production areas vary widely in any 1 year, mainly due to availability of irrigation water. Growers can own a mix of groundwater and surface water and a mix of surface water types, with different levels of security. In addition, they can have different approaches to trading water in and out of their business. Water markets and the government buying water from irrigators to preserve water flows for environmental purposes have been a feature of Australia's water policy over the past 15 years (Australian Government 2012).

\subsubsection{Description of 16 case study farms}

A case study design was chosen to better understand the evolution of a farming system with its environment and how this ongoing change is reflected in the internal organisation of the farms and the farmers' goals (after Darnhofer 2014, p. 548). A purposive sampling method was used to identify case study farms (Palys 2008). The chosen farms were in different locations, of different sizes, in family and corporate ownership (Pritchard et al. 2007), and with different types of workforces, different levels of exposure to irrigation water uncertainty and different levels of technology use. Farms willing to release performance information were preferred so that financial and economic data could be included in the analysis. Cotton farmers involved in a farm financial benchmarking activity run by an accountancy firm were invited to participate in the study (11 farms) (Cotton Comparative Analysis run by Boyce Chartered Accountants 2015). Five additional farms were the 11 financial benchmarking farms are not identified on the map to protect their identity

sourced through key industry informants recruiting participants using the sampling criteria. A total of 16 case study farms were involved and each was provided a pseudonym (Farms A through to P). Some farms not involved in the comparative analysis program did not have financial data for every year and so did not provide any financial analysis. For these farms, we relied on interviews/self-report of financial and economic performance.

Table 1 describes the case study farms, including their main biophysical (i.e. natural, physical capital), financial and workforce features, including their level of remoteness. Remoteness refers to Australia's classification of remote areas and primarily to the issue of accessibility to services and infrastructure, such as the distance people need to travel to access health and other services. Most farms in this study were in 'outer regional', 'remote' or 'very remote' Australia (ABS 2017). Remote and very remote areas are deemed to have very restricted/little accessibility of goods, services or opportunities for social interaction (ibid). The farms have been grouped on the basis of the range of cotton planting area reflecting the range in total workforce size between years, rather than the area planted in 1 year.

Case study farms are located in 'production valleys' in the states of Queensland and New South Wales (NSW). These valleys had experienced a large variation in irrigation water availability and in cotton area planted between 2012 and 2015. The location of case study farms and total area of cotton planting and yields in cotton production valleys by State is provided in Fig. 2.

\subsection{Conceptual frameworks for this study}

To understand how farmers' workforce strategies are formed and the implications for their adaptability, we draw on two 


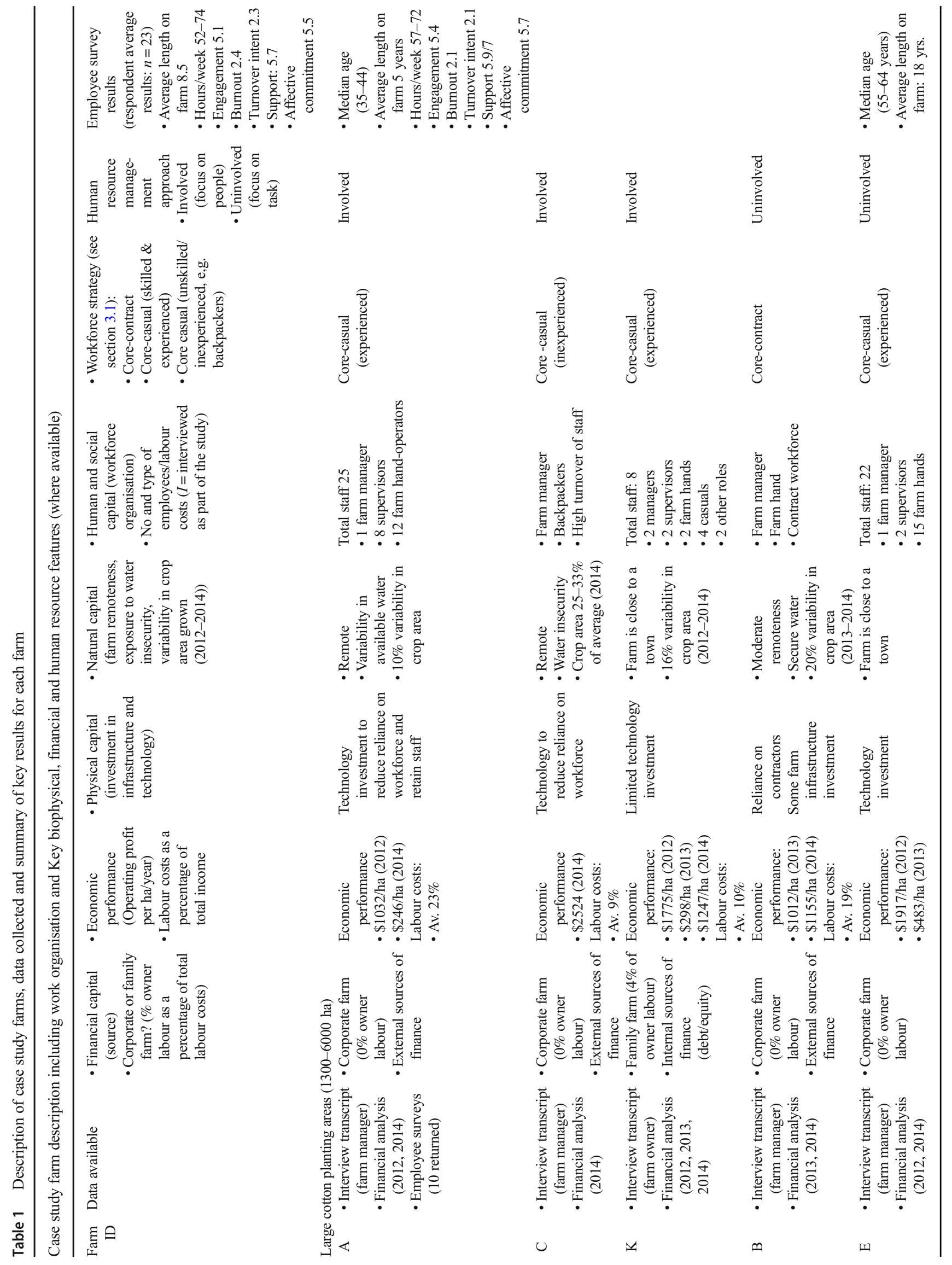




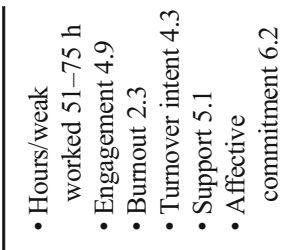

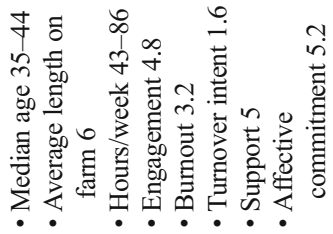

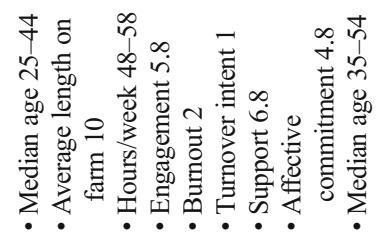

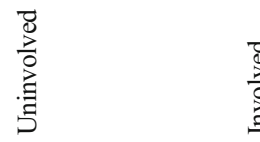

总

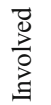

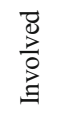

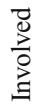

ن

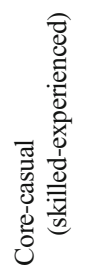

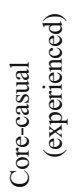

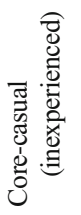

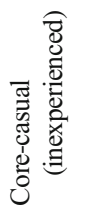

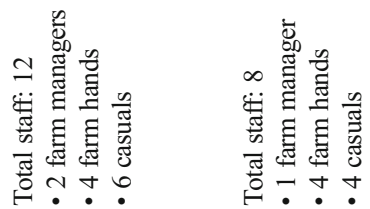

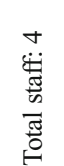

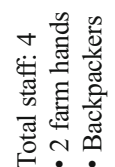

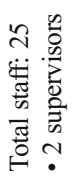

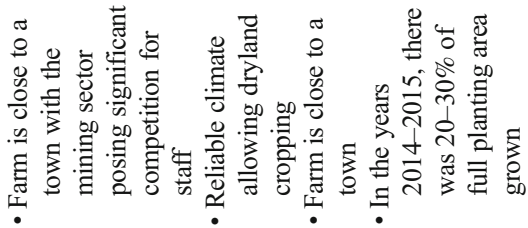

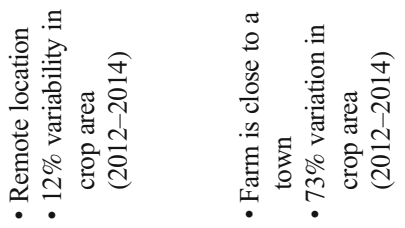

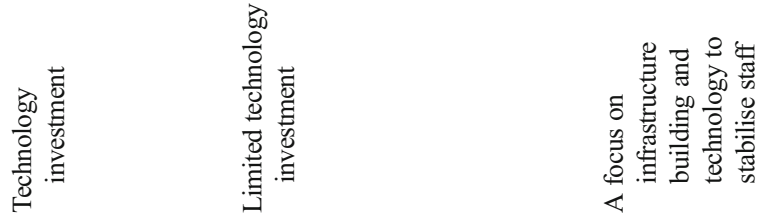

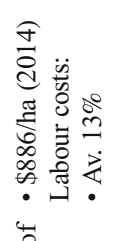

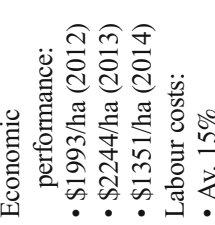

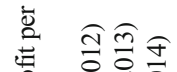

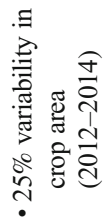

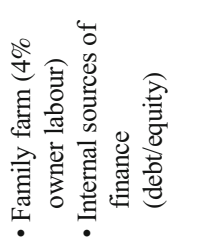

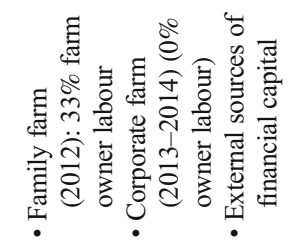

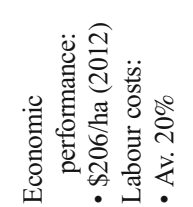

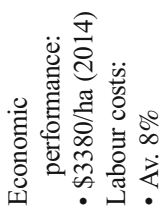

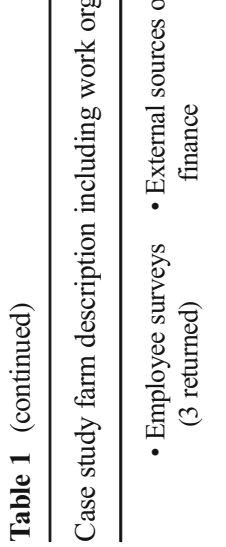
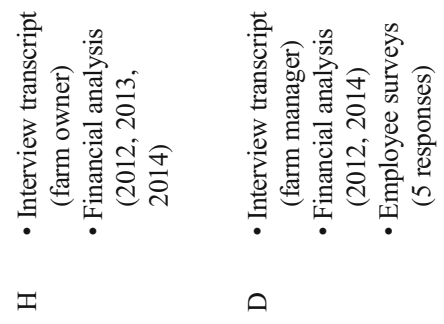

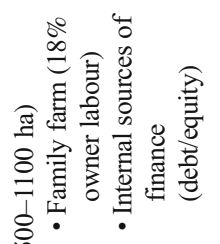
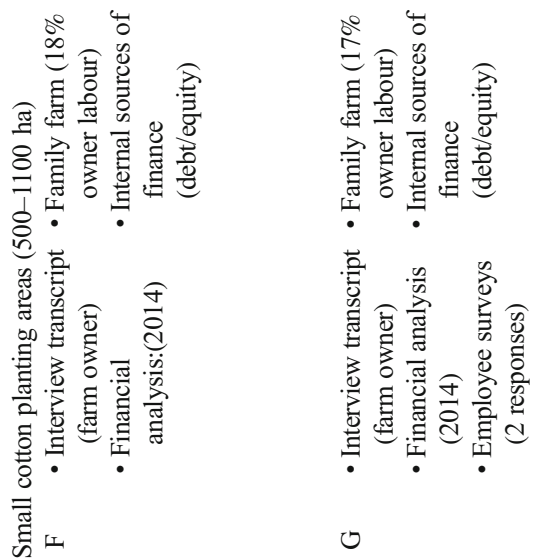

๕. 

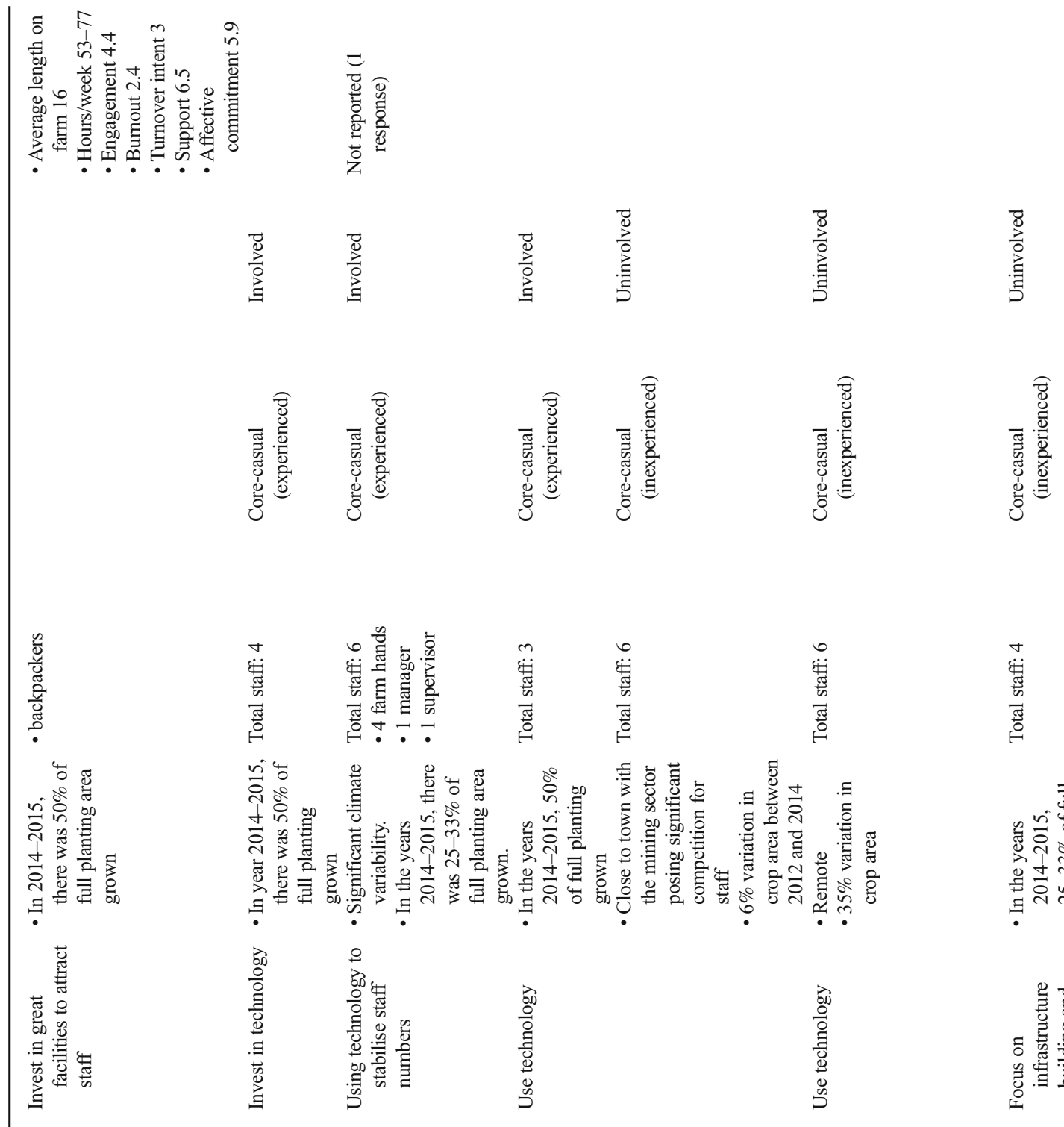

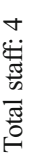
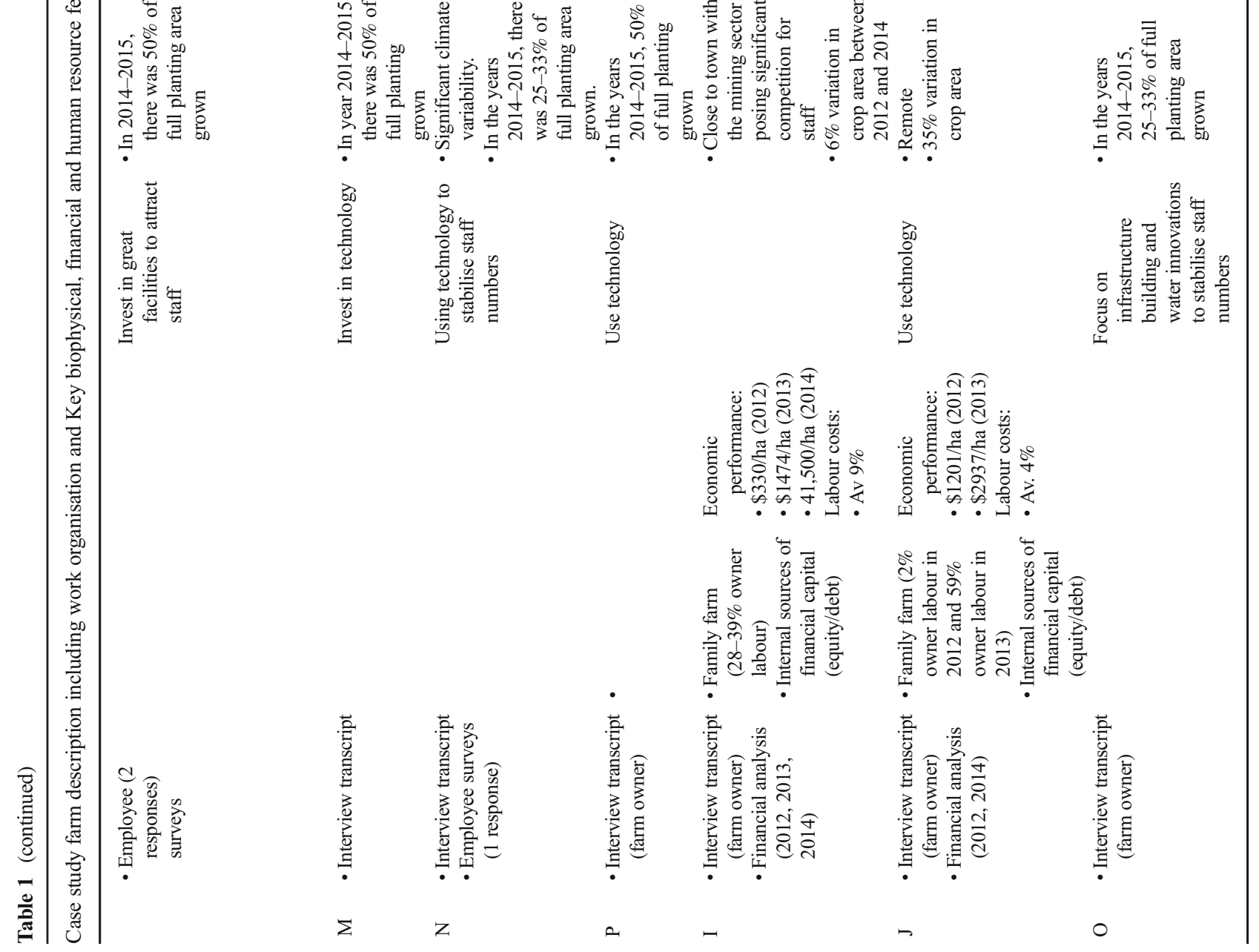
conceptual frameworks: the 'five capitals framework' and strategic human resource management.

\subsubsection{The five capitals framework}

We required a way to identify and analyse the influences and explanations for farm workforce strategies across a diversity of cotton production systems. The five capitals framework, defined in Table 2, considers the access to five types of 'capital': natural, financial, physical, human (including cultural capital, after Bourdieu 1986) and social capital The framework acknowledges the range of 'assets, income sources and product and labor markets' that make up a livelihood (Bebbington 1999, p. 2022) and the links between them.

The framework is commonly applied in rural livelihood studies (Scoones 1998; Bebbington 1999; Ellis 2000) and studies of adaptation (Nelson et al. 2010) to examine livelihood outcomes from access to capitals and the trade-offs, sequences and trends in the combinations and relationships between capitals (Scoones 1998). In selecting this framework, we adopt the suggestion of Darnhofer et al. (2014) that to understand adaptability at the farm scale, 'it matters how the components are linked and the way in which the resources are used, not just the resources themselves' (ibid: p. 549).

\subsubsection{Strategic human resource management}

One weakness of the five capitals framework and studies of farm adaptability more broadly is the conceptualisation of human and social capital, which focuses primarily on the education, skills and relational resources of the farm owner or farm family. Considering the broader farm workforce, including contractors and employees, required a way to analyse the intent of different workforce strategies chosen by farm owners, the approaches to managing people (human resources) and the experience of people at work in the context of farm challenges. We chose concepts within the management discipline, specifically related to strategic human
Table 2 Definition of the five capitals used in a 'livelihoods approach' (adapted from Bebbington 1988, Ellis 2000, Scoones 1998, Campbell et al. 2002)

Natural capital

Physical capital

Human capital (including cultural capital)

Social capital

\begin{tabular}{|c|c|}
\hline Capital type & Description \\
\hline \multirow[t]{2}{*}{ Financial capital } & Savings, credit, debt, equity. \\
\hline & $\begin{array}{l}\text { In this study, financial capital is inclusive of the following: funding source and } \\
\text { expectations of growth and dividends from different sources; superannuation } \\
\text { (pension funds); shareholder/company funds; banks (debt), family (equity); } \\
\text { other sources of credit; savings; assets }\end{array}$ \\
\hline \multirow[t]{2}{*}{ Natural capital } & Land, water and biological resources. \\
\hline & $\begin{array}{l}\text { In this study, natural capital is inclusive of the following: water resources } \\
\text { (quantity and reliability); weather and climate; land (quantity, quality and } \\
\text { fertility); location/remoteness }\end{array}$ \\
\hline \multirow[t]{2}{*}{ Physical capital } & $\begin{array}{l}\text { Produced by economic activity including infrastructure, equipment and } \\
\text { technology. }\end{array}$ \\
\hline & $\begin{array}{l}\text { In this study, physical capital is inclusive of the following: irrigation } \\
\text { infrastructure; staff accommodation; agricultural tools and machines; general } \\
\text { farm infrastructure that can support (or hinder) work performance. }\end{array}$ \\
\hline \multirow[t]{2}{*}{$\begin{array}{l}\text { Human capital (including } \\
\text { cultural capital) }\end{array}$} & $\begin{array}{l}\text { The social assets of a person (education, skills, management capacity, health) } \\
\text { that are admired and valued in particular social groups. These attributes are } \\
\text { considered to be both economically important, but also culturally important } \\
\text { for social exchange such as social status in work (Bourdieu 1986). }\end{array}$ \\
\hline & $\begin{array}{l}\text { In this study, human capital is inclusive of all people interested and available to } \\
\text { work in cotton; workplace culture on farm; management style of } \\
\text { owner/managers/employers and the knowledge, skills and experience of } \\
\text { everyone engaged in the farm business (e.g. family members, farm owners, } \\
\text { managers, employees, contractors). }\end{array}$ \\
\hline \multirow[t]{4}{*}{ Social capital } & $\begin{array}{l}\text { Formal and informal social resources that people draw upon in pursuit of their } \\
\text { livelihoods. Social resources are developed through investing time, effort } \\
\text { and other resources in membership of formal groups or organisations; social } \\
\text { interactions in and outside the workplace; reciprocal assistance. }\end{array}$ \\
\hline & In this study, social capital is inclusive of the following: \\
\hline & $\begin{array}{l}\text { - External social networks: affiliations and association memberships; training } \\
\text { sources; labour sources; community }\end{array}$ \\
\hline & $\begin{array}{l}\text { - Internal social networks: relationships of trust between employer and } \\
\text { employee; mutuality of interests; leadership provided by employer; } \\
\text { long-term employee loyalty; a team approach; the employer's approach and } \\
\text { empathy }\end{array}$ \\
\hline
\end{tabular}


resource management (SHRM) (Becker and Huselid 2006). SHRM focuses on organisational performance and the role of human resource management systems in solving business problems. 'Strategic' refers to the way advantages are realised and the system of capabilities to generate advantages. Porter's (1996) concept of the 'strategy activity system' is relevant in which actors 'deliberately choose[ing] a different set of activities to deliver a unique mix of value' (1996: p. 64) and in which there is no one 'best' workforce strategy (Becker and Huselid 2006). For instance, strategies that prioritise human resource stability and low turnover of people will often involve employers focusing on 'employee engagement', where employees feel vigorous, dedicated and absorbed at work (Albrecht et al. 2015). This concept, from the psychology of work, leads to benefits for employers and organisations in lower staff turnover (employees are less likely to leave a business) and a positive contribution to business performance. This strategy is also associated with 'high-performance work practices' of employers (Combs et al. 2006) and includes building effective teams, bonuses, flexible arrangements and training (Pfeffer 1998), which contribute to empowering, motivating and developing the workforce (Liu et al. 2007). These work practices have been linked to human sustainabilitywhere the work environment is not disruptive of people's health. These strategies and practices have also been linked to economic success (Pfeffer 2010). In the reverse, failing to retain high-performing employees can hold back business performance through chronic understaffing, which increases employee fatigue, risk of injury and workplace stress, as well as the potential of having a less-qualified workforce overall (Rappaport et al. 2003). These concepts broaden the scope of human and social capital to include the practices and dynamics of workplace relations in adaptability.

\subsection{Case study farm data collection}

\subsubsection{Farm owner or manager interviews}

The study sought to understand the current workforce organisation, how farmers' workforce strategies were formed and the implications for farm adaptation. An interview with the farm owner or farm manager was conducted face-to-face on each case study farm between 21 March and 5 June 2015. A semistructured interview format (Gummesson 2000) included questions related to the farming operations (i.e. land and water holdings, cotton production methods), workforce organisation (the number, type and forms of employment on farm) and workforce strategies (how farm workforce organisation supports needs and priorities of the farm). Questions related to human resource management practices and the experiences and challenges facing farm owners and managers were also asked. We drew on standardised questions relating to human resource management practices, such as practices to engage and retain staff. We adapted Scoones' (1998) checklist related to the analysis of livelihood resources including the following: the starting point for the farm and workforce strategy and the limits to access to capitals (sequencing), whether or not farm capitals were substitutable, or needed in particular combinations; trade-offs between resources in pursuing their strategy; and trends and threats in resource availability and access. The questions were related to the 2012-2015 production years to link responses with farm financial and economic performance information and to understand workforce changes between years. Interviews were audio-taped and transcribed for qualitative data analysis.

\subsection{Collection of farm economic performance information (2012-2014)}

The financial data for all farms that were willing to provide data via the Cotton Comparative Analysis was assembled. This was combined with farm asset (i.e. land and water holdings) and other farm demographic information obtained at the interviews. Financial analysis involved the calculation of farm profit metrics such as costs of production (per bale and per hectare), operating profit per hectare, return on assets managed (cotton enterprise), total labour costs as a percentage of income and owner/ family labour as a percentage of total labour costs. To investigate issues related to resource use efficiency, and to compare between farms, it was necessary to value owner/family labour at the amount that they would need to pay if the owner/family labour was replaced with paid employees. Financial and economic performance information was compiled for each farm for the years 2012, 2013 and 2014 where available. The 3 years of historical financial and economic performance data was considered important for providing insights into the impact of challenges on the case study farms, such as seasonal conditions, prices of inputs/outputs and the stage of development of the business. This data could be aligned with employer interview data about the changes in cotton planting area and staff numbers (Table 1).

\subsection{Case study farm employee survey}

Employees on case study farms were asked to complete a written survey. The survey asked them to provide demographic and descriptive information about themselves, their work and their career and adapted questions assessing their experience at work, including engagement (Shaufeli et al. 2006), burnout (Schaufeli et al. 1996; and several from Schaufeli et al. 2002), supervisor support (Hoang et al. 2013), turnover intentions (single item 'I often think about quitting this farm'; (Stanley et al. 2013) and commitment to the organisation (Allen and Meyer 1990). Employees were asked to indicate 
their general feelings or experiences at work: 'How often do you feel [experience] the following about [at] your work in general?'. Responses were recorded on a 7-point scale with the mid-point reflecting feelings or experiences some of the time $(1=$ never $; 7=$ always $)$. In total, 98 surveys were provided to 13 farms. Following reminder emails and phone calls, a total of 23 surveys were returned from 6 farms (43\% of respondents from one farm). One survey was not included as it was returned late and was the single response for that farm $($ farm $\mathrm{N})$. Because of the low number of returned surveys and the uneven responses between farms, all employee data is used descriptively. Of the returned surveys, $68 \%$ of respondents identified as supervisors with an average length of time in the cotton industry of 11.5 years and with their current employer 8.5 years (a summary of employee survey results on these questions is provided in Table 1).

\subsection{Integrative analysis}

Data from interviews with farm owners or managers, the available farm financial and economic performance and the completed farm employee surveys were compiled for each farm to form a detailed case study description (Mitchell 1983; Ragin 1987). Farm owner or manager decisionmaking related to the farm workforce was examined using the conceptual frameworks. Qualitative data analysis techniques were used (Stake 2005) in which segments of text from the interview transcripts were coded to the five capitals and relationships between the capitals (i.e. substitution, trade-offs and cumulative dynamics) coded to themes. Qualitative data analysis software was used (NVivo ${ }^{\mathrm{TM}}$ 2012). The relationship between farm business operations, workforce strategies and access to capitals was explored. Decisions and practices related to human resource management and strategic decisions of the farm business were also coded for their relationship with the five capitals. For each farm, the choices and impacts of the workforce strategies relative to the dynamics of the capitals for the farm business were examined. Reports of positive or negative consequences of the workforce strategies by farm owners, managers or employees were noted. A conceptual model of the dynamic interrelationship between the farms' capitals, workforce strategies, key impacts and influences was developed for each farm.

A cross-case analysis was conducted to distinguish patterns of responses that differentiated farms from others with respect to the relationship between capitals, workforce dynamics and human resource management practices (Patton 1990). Constant comparative techniques from grounded theory analysis approaches of the social sciences (Charmaz 2014) examined the dynamic interactions between capitals and workforce strategies used to sustain or change the cotton businesses within their particular context. The variation between farmers' strategies and patterns related to the formation of workforce strategies was examined.

\section{Results and discussion}

\subsection{Workforce organisation on case study farms}

Table 1 provides a summary of the workforce organisation and main workforce strategies on case study farms.

All farms held a small permanent workforce of one to three people, including the farm owner/manager and people in management roles or senior/experienced 'overseer' roles. This workforce was described by case study farms as 'core' (i.e. central, relied on) to what the farm owner or manager was trying to achieve. Even in difficult times, such as low cotton planting years with a need to focus on costs, this group of staff was seen as essential to retain. The following is an example of how farm owners or managers describe and prioritise their core workforce:

Now we've got our core staff...we really try hard to keep hold of our salaried guys, because we know it's very expensive for us to replace. But ...it is not necessarily in dollars... it is in ... productivity and it's in culture and for us, our culture is ... very important. (farm C)

We describe this type of workforce as 'core'.

Farm B used workers employed by labour hire or labour contracting firms (i.e. businesses that source skilled or unskilled workers for temporary work) to attract and manage all or part of their farm workforce. Some employers use this option to source a large seasonal workforce quickly (for instance, for irrigation or picking) so as to not be delayed by a recruitment and selection process. Others seek to 'outsource' the human resource management and administration function for the business. The responsibility for negotiating and maintaining the contract relationship and the day-to-day work of staff falls to the farm managers (the 'core' workforce). An example of the decision-making of farmers related to the use of contractors is described below:

We use full contract irrigation and full contract for infield operations; so planting, cultivating, harvesting, picking and spraying is all done on contract. We went to that contract model to bring in skilled people with the resources. The headaches that come with sourcing and managing all those staff ... We've just created that position where we're one step removed. I do understand that it is a big issue keeping skilled workers within the business. That is a disadvantage in our system, because if you want business continuity of corporate knowledge 
... that becomes difficult if you haven't got a second-incharge in training. (farm B)

All other farms used casual employees, employed on the basis of hours worked (usually paid at an additional $15-25 \% / \mathrm{h}$ compared to salary earners) with no entitlement to holiday or sick leave (Parliament of Australia 2015). Some cotton employers employed people casually who had experience working on cotton farms and with qualifications (i.e. vocational or trade level) to manage machinery. Defined as 'skilled casuals', these employees were drawn upon to fill seasonal workforce needs and complement the core workforce on a permanent or temporary basis. The casual nature of employment allowed for flexibility in the size of the workforce to adjust to the planted area, influenced by water availability and seasonal conditions. An example of the reasoning of employers for the use of casuals was:

If people have left here, over the last 10 years, it's because the work's not there. We're not growing the same amount of cotton. The biggest cost of when someone leaves is the money you've invested in them...Lost expertise; that can be an issue. (farm I).

Five of the farms used 'unskilled' employees, those without cotton production experience or qualifications related specifically to machinery use and maintenance. Australia's working holiday visa scheme for 18-30-year-olds from nominated countries (Australian Government 2017) was being used widely by cotton growers. Travelling holiday makers required increased time and effort for managers in induction and training. An example of the reasoning of employers for the use of casuals is provided below:

The ones with the better work ethic are the ones that travel. Because they're not frightened to get out, leave their comfort zone and go out and look for work. We've had American guys, Irish, we had Estonians. (farm E) The beauty of backpackers is that they're happy to come in, sometimes we might only need them for two months, so they can come in, do the work and go. (farm C)

This workforce organisation of 'core', 'contractors' and 'casuals' on case study farms reflects the increasing trend of temporary and contract workforces in agriculture reported in industrialised nations outside Australia, such as in France and the UK (Ball 1987; Errington and Gasson 1996; Madelrieux and Dedieu 2008). Whilst we did not look specifically at intrayear work organisation with respect to who does what, when, where, how and why as used in work assessment methods (Madelrieux and Dedieu 2008), nor the family work dynamics and pluriactivity examined in other studies (Benjamin and Kimhi 2006), we find parallels with the description of the 'basic unit' in livestock farming (Madelrieux and Dedieu 2008) and the 'core' workforce described on cotton farms. Whilst in many countries, this unit consists of mainly family members, here, the core group included up to three permanent employees. In addition to confirming the international trends, farm decision-making about the type of workforce in this study was linked to coping with the challenges of resource constraints such as water for irrigation. This relates to the role of the workforce in meeting the priorities and needs of the farm business, or the workforce strategies, which are discussed next.

\subsection{Workforce strategies}

The diversity in farm workforce organisation between farms was related to different workforce strategies. The importance of the 'core workforce' concerned a medium-term focus for sustaining farming operations between seasons. Contract and casual staffing are a response to shorter-term, or within season, operations. The results suggest that farmers recognise the trade-offs in workforce decisions and are aware of the potential longer term consequences, for instance, in favouring contract staff over training a manager. Some case study farmers (e.g. farms A and M) spoke of their preference and capability to avoid turnover of staff or secure a stable or permanent staffing regime; others (e.g. farms $\mathrm{C}, \mathrm{K}$ and $\mathrm{G}$ ) spoke of their capability to manage high turnover of staff to enable flexibility and responsiveness in farming operations. Grouping the farms on the basis of their workforce organisation, three main workforce strategies were defined: (1) core and contract; (2) core and casuals (skilled) and (3) core and casuals (unskilled) (Table 1). The strategies are different combinations of different types of workforces in terms of skills (competence), experience (know-how) and period of employment that assist the farm owner or manager to achieve their goals in farming.

These strategies support the findings of Madelrieux and Dedieu (2008) that not all workers are interchangeable. Case study farm owners and managers prioritised their 'core workforce' in terms of retention and development. Contract and casual staff represented 'room to move' in farming operations or flexibility (Dedieu 2009, p. 402). These three forms of workforce strategies contribute to understanding the hierarchy of importance of workforce decisions and the drivers for farm workforce organisation. Next, we explored the influences on choice of workforce strategies applying the five capitals framework.

\subsection{Influences on the choices of workforce strategy}

The influence of the farm owner or manager's sources of 'capital' (natural, physical financial, human, social) on the workforce strategies described in section 3.2 was examined. The relative importance of each of the capitals and their 
influence on workforce strategies is described next, starting with the results from the financial analyses of case study farms.

\subsubsection{Financial capital}

Analysis of data from 11 of the 16 case study farms revealed substantial profit variation between farms (\$20 to \$282 per bale and $\$ 206$ to $\$ 3380$ per hectare) (Table 1). Further, the farms that provided more than 1 year of data also showed substantial variation between years. Years with low profit were associated with issues such as reduced irrigation water availability. The return to total assets managed varied from 1 to $18 \%$, with substantial variation between farms and between years on the same farms. One of the farms with a belowaverage operating profit per ha had a relatively high return to total assets managed as the asset values for land and water were relatively low. Overall, there was no identifiable relationship between the workforce strategies (i.e. use of core-contract, core-casual skilled or unskilled people), workforce costs and economic performance of the farms.

The source of financial capital on case study farms, however, was linked to particular workforce strategies, particularly the use of contract and casual (unskilled) workforces. Corporate case study farms (where the ownership and management of the farm is separated) were mainly resourced by superannuation funds (also referred to as pension funds). Other sources of finance for these farms were public or private companies. In contrast, family case study farms drew on debt (bank credit) or family sources (equity). Workforce strategies on these farms involved core-casual (skilled and experienced) employees and decisions that avoided the use of temporary workers or inexperienced employees.

The case study farms with external financial capital sources (superannuation and shareholder sources) were found to make decisions primarily related to their natural and physical assets, which then flowed through to affect their human resources. For instance, investments in land and water were chosen primarily based on the returns that are able to be achieved. The workforce was seen in terms of the labour they provided, often with reliance on short-term/casual workers. Larger farms, farms in remote areas (cheaper land) and those faced with water scarcity (i.e. from seasonal and climate variability or government water reforms) were more likely to adopt this strategy (e.g. farms A, C, B, E, H). Recruitment of a workforce relied on 'anyone who will work under the farming system'. This led to high turnover of casual staff and higher costs related to recruitment, training, potential errors, higher maintenance costs of machinery and, in some cases, employer fatigue.

We have some casuals that come and go when we are irrigating...we don't necessarily know them all very well. (farm C)
Case study farms with external financial capital resources were more likely to choose contractors in their workforce strategies. This shifted the costs associated with machinery ownership (i.e. physical capital) to return on investment (i.e. financial capital).

Each machine costs you about a million dollars and we need to get our crops off in a month. We would probably need four of those, so it's a lot of capital tied up in machinery that only gets used a month in a year. So we find your better off to do that with contractors. (farm B)

The large variation in economic performance on each farm between years reflects the challenge for cotton producers in continual adjustment in all aspects of farm operations and the difficulty in achieving stable economic performance. The results are inconclusive with respect to the relationship between workforce strategies and farm economic performance, and labour cost on its own is a very broad measure for total workforce input that does not capture differences in labour quality or productivity. However, the results show that farms have a threshold for workforce costs and the choice of particular workforce strategies is related to the source of financial capital and the importance of returns to assets managed (land and water). This is the first time workforce costs and sources of financial capital have been specifically examined in the context of farm adaptability. We found that workforce organisation and farmers' workforce strategies were influenced by the relative importance of these priorities. This supports the finding from crop-livestock studies that suggest farm work is 'an adjustment variable to mitigate effects of scarce land and/or capital' (Srairi and Ghabiyel 2017, p. 31). In our study, we find the workforce facilitates the management of variability.

\subsubsection{Natural capital}

Case study farms had different levels of exposure to constraints related to the quantity, reliability and quality of land and water resources, and exposure to weather and climate variability. This exposure influenced management actions and, in particular, flexibility in workforce numbers. Case study farms with lower asset values for land and water, and therefore less reliable water, encountered more variable production, which affected workforce demand. Variability in crop size between years was significant on some farms. One farm manager reported:

We're growing $12 \%$ of the size crop we grew last year. We've had no water coming into this season. (farm C)

Another described the rapid workforce expansion needed when water availability improved post-drought: 
When we came out of the drought in 2010, it was difficult. We had to start again. We had to build from 12 people to 40 in a hurry. (farm A)

In contrast, other case study farmers with access to more reliable water, or in locations favourable to dryland crops, reported greater workforce stability:

Having dry land cropping has certainly given us a balance for the workforce requirements through the year and that's been a real help. Plus, we're in an area which is somewhat reliable for rainfall compared to the west, so we actually do harvest a winter crop, virtually every single year. There's ... work all year around. (farm F)

Another noted: 'We've only reduced our area once in about 48 years.' (farm O).

The positive impact on employees from more reliable water was raised by one farm employer, who said they were able to recruit a good manager who was 'burnt-out' by previous positions in which employees were laid off every year or two depending on water availability (farm B).

The farms with more reliable water had a stable, permanent workforce over many years and were now investing in efficiency measures and technologies to reduce the workforce in the irrigation season, linking resources of natural with physical capital (e.g. farms A, B, E, H).

The geographic location of farms, their exposure to climate variability and their level of remoteness had different impacts on the ability to attract and retain a workforce and, therefore, the farm owner or manager's workforce strategies. Some farm owners and managers believed isolation or remoteness hampered staffing options (farms C, D, F) especially when towns and their services can provide incentives or attract different groups, such as younger employees (Farm G). Others viewed it as an advantage because it reduced competition from other farmers or alternate industries (farms A, I). One case study farm associated competition from the mines as a factor in 'having to use backpackers' (farm I). Others noted that travelling long distances was a problem for staff. The location of the farm (and the services available at that location) influences the initial attractiveness of a position to employees. In the employee survey responses, several commented on the availability of services and proximity to towns as a key factor influencing their opinion of their workplace.

All case study farms described the influence of their location and water availability as a factor in their workforce decision-making, with increased variability or insecurity in climate or water availability linked with workforce strategies of core-contract and core casual (inexperienced).

Case study farm owners and managers can be seen to develop a workforce advantage from their location or choose alternate workforce options as a consequence of location constraints. Whilst remoteness is recognised as an issue in attracting and retaining workforces, particularly in Australia (McKenzie 2011), the influence on farm workforce strategies and the management of farm workforces as a consequence has not been previously described. Our results suggest that any understanding of farm system adaptability and the influence of the external environment and resources must consider the dimension of 'remoteness' and the intersection with workforce considerations such as labour markets and employee services.

\subsubsection{Physical capital}

Case study farm owners and managers said technological advances in cotton production and labour-replacing technologies had an impact on their workforce requirements, both in total workforce numbers and the skills and capabilities required. For example, one farmer spoke of the reduced need for cultivation due to plant breeding and an increased need for an irrigation workforce:

'Instead of being in there and cultivating with tractors 2

3 times, you spray it once or twice, the requirement for labor has dropped, but you still need a lot of labor to start [irrigation] siphons. (farm L)

The investment in physical capital was part of farm decisionmaking related to retaining relatively skilled people as core staff. This was more prevalent on family farms than corporate farms, where technology investment was more difficult to justify to sources of external financial capital focused on short-term returns.

Some case study farms specifically noted their investment in machinery and technology was related to 'trying to reduce staff numbers', 'reducing over-reliance on staff' or 'increase efficiency' (farms L, F, O) or to 'be more attractive to staff' (farm N). One farm owner said such investment was 'too expensive' and they recruited more staff to cover picking and irrigation (farm G).

Nine of the 16 case study farms specifically related decisions concerning physical capital resources to their workforce strategies. Infrastructure and technology had a dual role in replacing labour and in attracting and retaining the core workforce. This re-enforces the reported benefits and disruptive impacts of technologies in the workplace more broadly (Wallace 1989).

\subsubsection{Human capital}

Some case study farm owners and managers prioritised the importance of the knowledge, skills and experience of everyone working in the farm business and, through their 
management style, emphasised the development of employees and the importance of establishing a favourable workplace culture,

'I expect everyone to bring something to the farm, more than what I currently know.' (farm A)

Farm workers who have built up experience of the farm over a period of time were seen to have valuable understanding of its complex operations:

He understands the water and he understands the whole system and all of that; it would take a while to get somebody else up to speed with that. (farm G)

Whilst retaining employees was a challenge with the variability of production, these case study farms recognised the value of their employees' experience and the importance of retaining people:

It's definitely challenging, but pretty satisfying as well, to be able to keep someone on, because really that level of experience you can't beat that really. After 2-3 years people start getting good at what they're doing, but after five years they become quite reliable, it's really invaluable. (farm P)

These farms prioritised the retention of core staff through times of low production. Across the case study farms, the extent to which human resource management considerations were prioritised in farm business strategies differed. Some farm owners and managers displayed 'involved' management (farms A, C, K, D, F, G, L, M, N, P), demonstrating pro-social actions (e.g. reciprocity) toward their employees and were likely to make workforce decisions that are primarily related to maintaining stability or capacity in the workforce. 'Uninvolved' management (farms B, E, H, I, J, O) gave less priority to the impact of workforce change on employees or the work environment in the overall business context (Table 1).

The employee survey further explored the implications of the different workforce strategies for farm adaptability and the impact on employees. Employees responding to the survey on 'involved farms (A, D, G, L) and uninvolved (E) worked on average $20 \mathrm{~h} /$ week more during busy periods (average of 52$74 \mathrm{~h}$ ). While long working hours (if sustained or at unfavourable times) can be detrimental to the health and well-being of employees, the farm employees surveyed reported moderate levels of engagement (5.1/7) and low intention to quit (2.3/7), suggesting that they were motivated at work: absorbed in, enthusiastic about and dedicated to their jobs. This may be because these employees felt relatively high levels of support from their supervisors (5.7/7) and were emotionally committed to the farms that they worked on (5.5/7).
They were also experiencing lower levels of burnout (2.4/7), a job-related stress condition linked to experiencing lots of demands at work. While burnout is linked with poor outcomes for employees and businesses, engagement is consistently linked with positive outcomes, such as better well-being and performance (Shaufeli et al. 2006). These results of our study suggest that some farm owners/managers were providing employees with additional resources at work and these resources can help employees deal with job demands, increase engagement and reduce burnout, irrespective of the workforce strategy chosen. The results suggest that the human resource management practices of farm owners and managers could mediate the negative impact on people of long work hours or heavy workloads within a season or workforce changes between seasons. While human resource management practices that support employee engagement are known to contribute to business performance in general (Shuler 1992; Albrecht et al. 2015), it has not previously been explicitly recognised as a mediating factor in farm employees' experience of work and in moderating impacts from workforce flexibility.

It is also important to keep in mind that this small number of employee surveys may not be representative of the majority of employees on cotton farms. For example, employees may have elected to participate because they were engaged at work or emotionally connected to the farm, or may not have wanted to report poor workplace conditions in case their manager saw their responses. However, employees were informed that their data would only be presented in aggregate and they were provided with the option to have their responses omitted from any farm reporting to help reduce this concern.

The human resource management responsibilities of workforce change and inter-personal interactions in the workplace rested largely with the farm managers. In the farm manager interviews, some sought to distance themselves from directly dealing with the level of flexibility required in the workforce through the use of labour contracting firms and others reported fatigue from, and concern with, constant workforce change:

[Because of the low water allocation], basically we let two good people go. All those casuals will be gone and part time will be gone. ... It was a great pain. Terrible. But anyway, they all moved on to better things, we hope. (farm K)

This provides additional evidence that focusing solely on workforce costs as a measure of human and social capital or as a source of vulnerability in adaptability in farming can hide the human well-being dimensions of adaptability and not account for the management of the workforce as an adaptive practice.

Whilst flexibility in production and the workforce is a feature of all the farms studied, flexibility (as reflected in intraannual workforce changes) can have negative consequences 
for farm managers and employees. This is significant for scientists' understanding of farm adaptability. To date, flexibility and its relationship to 'high adaptability' have been largely considered a positive and desirable attribute of farming systems (Nelson et al. 2010; Marshall et al. 2013). The tension between the organisational value of flexibility (e.g. for a farm adapting to the operating environment) relative to the individual or worker impact of such flexibility, and whether one is at the expense of the other (Hill et al. 2008), requires further investigation. As argued by Dedieu (2009), it is important to look at how farmers work with uncertainties rather than smooth them out, and here, we find the farm workforce a part of operational flexibility and a response option for constraints from climate or water and priorities for financial returns (external capital). These findings support the argument that limits to adaptation (for instance with respect to climate change) are constructed, rather than set, by resourcing limits and are strongly influenced by contested values (Adger et al. 2009).

\subsubsection{Social capital}

Some case study farm owners and managers took an interest in the employees' life beyond the farm and described the importance of community for their workforce strategies. One case study farm owner said: 'My interest is not just in what they do on farm, but off farm as well.' (farm M).

These employers tended to recognise wider motivations of employees in work, such as having task variety, opportunities to take responsibility and valuing their opinions:

We spend a lot of time walking around the workshop talking about things, about why we're doing things, what are their ideas? How do we fix this problem? (farm F).

Farm owners reported relying on their social network to source reliable employees or to get jobs for employees that they are unable to keep employed:

A lot of farmers have to advertise, but for me it's all word of mouth between families and friends in town. If you just tell someone in the tool store you're looking for a person, then someone will come in the next time looking for a job, they'll go, 'oh, call this farm'. That's pretty well how it works. (Farm P)

This expands the consideration of social capital to include the mobilisation of networks related to the workforce (Marshall 2010).

Section 3.3 has described and discussed the results from data collected from case study farms. We synthesised and generalised the findings across all farms to describe two main scenarios in a conceptual model describing the dynamic inter- relationships between the farmers' sources of capital, their workforce strategies and management practices in response to challenges (Fig. 3).

The model represents farm owners' and managers' decisions about their workforce organisation and workforce strategies as being a result of a dynamic interaction between their sources of financial, physical and natural capital. Whilst all farms held a small 'core' workforce, case study farms with external sources of financial capital, with less secure water holdings and locations of high climate variability or remoteness affecting local labour markets, used contract and temporary (casual and inexperienced) forms of work organisation for flexibility (scenario 1). In contrast (scenario 2), case study farms with family and internal sources of financial capital, with more secure water holdings and in locations with less climate variability and closer proximity to a town, were seen to use longer term, experienced employees (stability). The different strategies offered response options, with seasonal, temporary and contract workforces providing a way to respond to challenges with water resource availability or to drive investment in particular technologies or infrastructure and so reduce the reliance on a workforce. The farm workforce was a source of flexibility to preserve the functioning of the farm business for owners or to serve the priorities of shareholders that lie outside the farm.

Examining the workforce management practices of owners and managers and the working experience of some farm employees showed that the owners and managers who placed a high importance on the human and social capital in the farm business valued workforce stability and mediated or moderated the negative impacts of resource constraints.

Farm workforce strategies are therefore a central part of the farm owners' adaptive capacity (Marshall et al. 2013), although not always considered as part of strategic actions (Schuler 1992). Flexibility is considered a key aspect of adaptive capacity, and in this study workforce strategies are related to both operational flexibility (i.e. short-term responses related to staffing levels for increased or reduced water availability) and strategic flexibility (i.e. long-term choices related to changes in resources and farm organisation as well as new enterprises). In this regard, the farm workforce is a crucial factor for farm performance but also to adaptability (Dedieu 2009; Srairi and Ghaniyel 2017).

These findings are significant. Previous studies have acknowledged that the farm workforce is an important aspect of farm system adaptation and for the resilience of family farms (Dedieu 2009; Darnhofer et al. 2010; Darnhofer et al. 2016). We have shown that the farm workforce enables adaptation in natural, physical and financial capitals and is also affected by the re-organisation of these capitals. The impacts concern farm owners and managers as well as the broader farm workforce. This interrelationship means the people are absorbing the vulnerability of 'highly adaptable' farming 


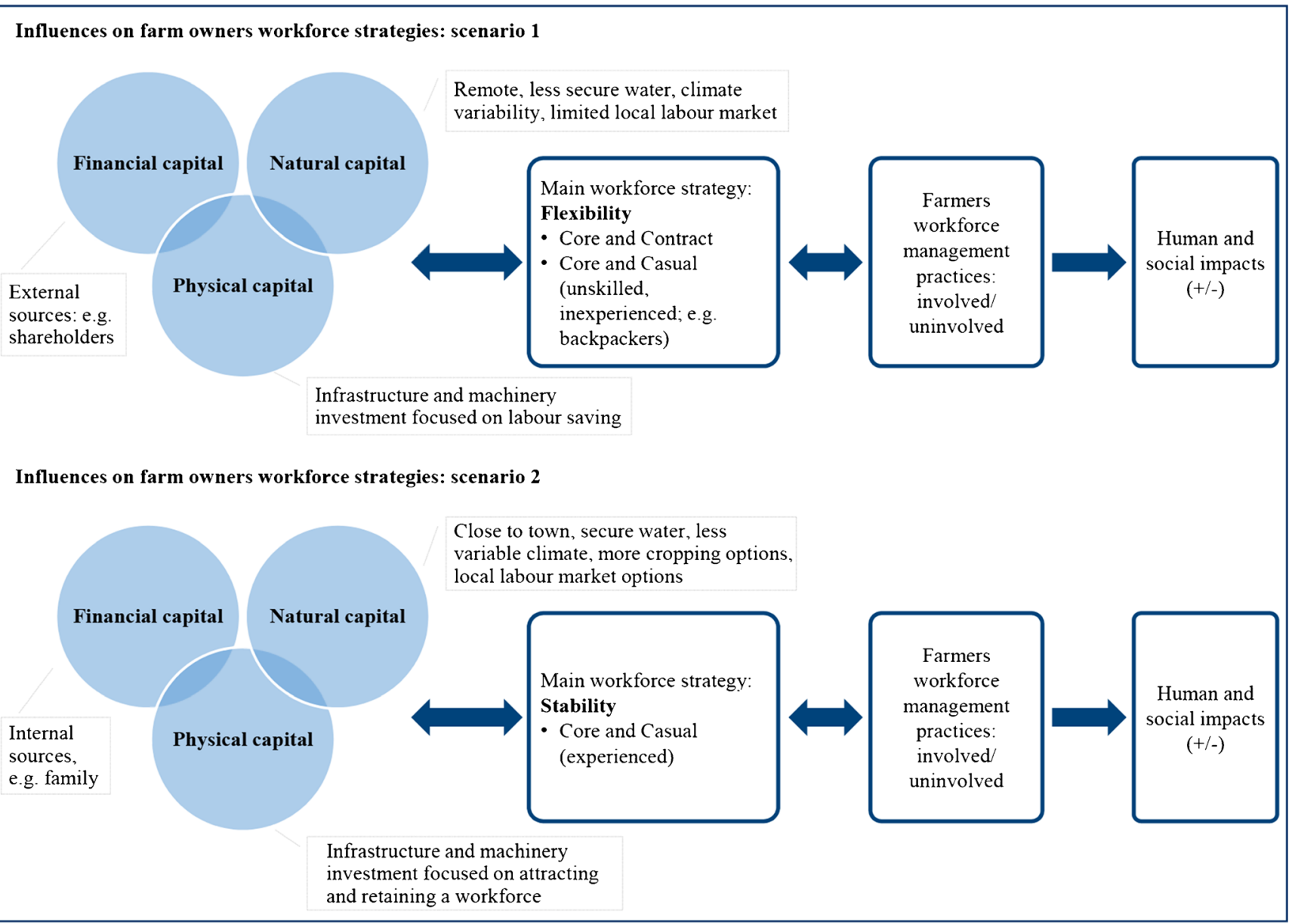

Fig. 3 A simplified conceptual model using two scenarios of the dynamic inter-relationships between the farmers' sources of financial, natural and physical capital, workforce strategies and management practices

systems. The impact, risks and vulnerabilities for people within 'highly adaptable farms' have not been well understood to date, nor have the substitution and trade-offs between physical and financial capital (e.g. farm machinery and technology) and human capital (skills and experience of the farm workforce).

\section{Conclusion}

This paper set out to understand farmer's workforce strategies (i.e. how farm workforce organisation supports the needs and priorities of the farm), how workforce choices are made and the implications of different strategies for adaptation. Sixteen case study farms in the Australian cotton production sector were examined and we found three types of workforce strategies being implemented: (1) core and contract, (2) core and casuals (skilled) and (3) core and casuals (unskilled). These strategies were as a result of a dynamic interrelationship between the farm owner and managers sources of financial, physical and natural capital that favoured flexible (core- influencing farm adaptability. The impacts for human and social capital from this dynamic can be either positive or negative

contract or core-casual inexperienced/temporary) or stable (core-casual/skilled) forms of work organisation. The active management of workplace conditions and the employee experience by farm owners and managers had a generally positive impact on employee engagement, moderating negative wellbeing impacts from highly flexible workforce strategies, such as employee burnout. Constant workforce change to enable flexibility in farm operations on some farms had a negative impact on farm owners' and managers' experience of farming. Whilst no direct relationship between the workforce strategies and farm economic performance was found, the large variation in farm economic performance between farms and between years on the same farms highlighted the overall challenge for farm management.

The interrelationship between farm workforce strategies and other capitals is important for adaptability in that the farm workforce is both a response option and is also affected by responses chosen from other areas, with flow-on effects that encompass human health and well-being, employment options in rural communities and the investment in technology. Negative consequences of adaptability related to risks and 
vulnerabilities fell on the farm workforce managers (making the decision to retrench workers) or the employees themselves (finding alternative work - often not an option within the same community facing the same constraints, such as water availability). For the first time, the finding that high flexibility, and therefore adaptable farms, can create vulnerabilities for the farm workforce and that different workforce strategies have different risks and consequences has been elaborated. It is this level of detailed analysis that many researchers of farm adaptation have called for (Nelson et al. 2010). There is also a desire to improve understanding of transformability (Marshall et al. 2014) and this requires multi- and trans-disciplinary research and integrated analysis (Srairi and Ghaniyel 2017), such as provided in this study. Without such analysis, the likelihood of farm adaptation could be overestimated or misrepresented and recommendations to further increase adaptability could be misguided.

Overall, the study demonstrates the importance of farm workforce strategies in farm adaptation and, therefore, the need for the farm workforce to be factored in to farm systems analysis, particularly with respect to sustainable development outcomes. Transformations in work organisation on farms need to be considered alongside the emerging agronomic or technological options being put forward as important for adaptability. To this end, the conceptual framework, multi-disciplinary approach and mixed methods used in this study provide some guidance for researchers, policymakers and practitioners to incorporate the farm workforce in order to better understand farm adaptability.

The inclusion of the 'strategy activity system' (Porter 1996) related to human resources enabled the impacts of adaptation to be better understood from the employees' and managers' perspective as well as revealing the farm management practices related to human resources that are conducive to the productivity and retention of human and social capital. Asking 'what farm workforce options may be possible?' and 'what could be the potential impacts from workforce responses?' provides additional assessment criteria for the evaluation of technological or other options and broadens the conceptualisation of social and human capital beyond the farm owner and family.

Further research on workforce dynamics in farming systems across more farms and different sectors is warranted. This should focus on better understanding of the role of farm workforce organisation and strategies under less extreme external variability; further development of analytical frameworks and methods for farming systems analysis inclusive of the farm workforce (Therond et al. 2017); and examination of the institutional context for adaptability, given the importance of water policy and industrial relations policy in this case (e.g. the availability of overseas workers and the laws governing casual employment).
Acknowledgements The authors acknowledge the Cotton Research and Development Corporation funding for this research and the time and support of Boyce Chartered Accountants, the project advisory committee, the cotton growers and the employees involved in the research.

Funding This study was funded by the Australian Cotton Research and Development Corporation (CRDC) (Grant number UM1501).

\section{Compliance with ethical standards}

Conflict of interest The authors declare that they have no conflict of interest.

Open Access This article is distributed under the terms of the Creative Commons Attribution 4.0 International License (http:// creativecommons.org/licenses/by/4.0/), which permits unrestricted use, distribution, and reproduction in any medium, provided you give appropriate credit to the original author(s) and the source, provide a link to the Creative Commons license, and indicate if changes were made.

\section{References}

ABARES (2015) Australian bureau of agricultural and resource economics and sciences Australian crop report, Canberra

ABS (2017) Australian Bureau of Statistics, The Australian statistical geography standard (ASGS) remoteness structure http://www.abs. gov.au/websitedbs/D3310114.nsf/home/remoteness+structure. Accessed 4 July 2017

Adger WN, Dessai S, Goulden M, Hulme M, Lorenzoni I, Nelson DR, Naess LO, Wolf J, Wreford A (2009) Are there social limits to adaptation to climate change? Clim Chang 93:335-354. https:// doi.org/10.1007/s10584-008-9520-Z

Albrecht SL, Bakker AB, Gruman JA, Macey WH, Saks AM (2015) Employee engagement, human resource management practices and competitive advantage: an integrated approach. J Organ Eff: People Perform 2(1):7-35. https://doi.org/10.1108/JOEPP-08-2014-0042

Allen NJ, Meyer JP (1990) The measurement and antecedents of affective, continuance and normative commitment to the organization. $\mathrm{J}$ Occup Organ Psychol 63(1):1-18. https://doi.org/10.1111/j.20448325.1990.tb00506.x

Australian Government (2012) The basin plan. https://www.legislation. gov.au/Series/F2012L02240. Accessed 10 July 2017

Australian Government (2017) Working holiday visa-sub-class 417. http://www.border.gov.au/Trav/Visa-1/417-. Accessed 10 July 2017

Bahn S (2014) Migrant workers on temporary 457 visas working in Australia: implications for human resource management. Asia Pac J Human Resources 52:77-92. https://doi.org/10.1111/1744-7941. 12018

Ball RM (1987) Intermittent labour forms in U.K. agriculture: some implications for rural areas. J Rural Stud 3(2):133-150. https://doi.org/ 10.1016/0743-0167(87)90029-5

Bebbington A (1999) Capitals and capabilities: a framework for analyzing peasant viability, rural livelihoods and poverty. World Dev 27(12):2021-2044. https://doi.org/10.1016/S0305-750X(99) 00104-7

Becker BE, Huselid MA (2006) Strategic human resources management: where do we go from here? J Manag:899-920. https://doi.org/10. 1177/0149206306293668

Benjamin C, Kimhi A (2006) Farm work, off-farm work, and hired farm labour: estimating a discrete-choice model of French farm couples' 
labour decisions. Eur Rev Agric Econ 33(2):149-171. https://doi. org/10.1093/erae/jbl002

Bourdieu P (1986) The forms of capital. In: Richardson J (ed) Handbook of theory and research for the sociology of education. Greenwood, New York, pp 241-258

Boyce Chartered Accountants (2015) Australian Cotton Comparative Analysis. http://www.boyceca.com/boyce-newsfeed/category/ australian-cotton-comparative-analysis/page/2. Accessed 12 July 2017

Campbell B, Sayer JA, Frost P, Vermeulen S, Ruiz-Pérez M, Cunningham A, Prabhu R (2002) Assessing the performance of natural resource systems. Conserv Ecol 5(2):22 http://www.consecol.org/vol5/iss2/ art22/

Charmaz K (2014) Constructing grounded theory. Sage Publications, London

Combs J, Liu Y, Hall A, Ketchen D (2006) How much do highperformance work practices matter? A meta-analysis of their effects on organizational performance. Pers Psychol 59(3):501-528. https:// doi.org/10.1111/j.1744-6570.2006.00045.x

Commonwealth of Australia (2015) Agricultural competitiveness white paper, Canberra, February. ISBN 978-1-925237-73-3

Cotton Australia (2016) The Australian Cotton Industry. http:// cottonaustralia.com.au/cotton-library/fact-sheets/cotton-fact-filethe-australian-cotton-industry. Accessed 12 July 2017

CSIRO, Bureau of Meteorology (2015) Climate change in Australia information for australia's natural resource management regions: technical report, CSIRO and Bureau of Meteorology, Australia

Darnhofer I, Bellon S, Dedieu B (2010) Adaptiveness to enhance the sustainability of farming systems. A review. Journal of Agron Sustain Dev (2010)30:545-555. doi:https://doi.org/10.1051/agro/ 2009053

Darnhofer I (2014) Resilience and why it matters for farm management. Eur Rev Agric Econ 41(3):461-484. https://doi.org/10.1093/erae/ jbu012

Darnhofer I, Lamine C, Strauss A, Navarrete M (2016) J Rural Stud 44: 111-122. The resilience of family farms: towards a relational approach. https://doi.org/10.1016/j.jrurstud.2016.01.013

Dedieu B (2009) Qualification of the adaptive capacities of livestock farming systems. Rev Bras Zootec 38:397-404. https://doi.org/10. 1590/S1516-35982009001300039

de Garis SA (2013) the cotton industry in Australia: an analysis. In 19th Annual Pacific-Rim Real Estate Society Conference, Melbourne, Australia, 13-16 January 2013

de Vetten L (2014) A comparison of methods assessing soil compaction on black vertosols. South-Eastern Queensland, Australia. Wageningen University, Netherlands

Ellis F (2000) Rural livelihood and diversity in developing countries, Oxford University Press, Oxford

Errington A, Gasson R (1996) The increasing flexibility of the farm and horticultural workforce in England and Wales. J Rural Stud 12(2): 127-141. https://doi.org/10.1016/0743-0167(96)00008-3

Findeis JL, Vandeman AM, Larson JM, Runyan J (2002) The dynamics of hired farm labour: constraints and community responses, CABI Publishing. ISBN 9781845933371

Gummesson E (2000) Qualitativemethods inmanagement research, 2nd Edn. Sage Publications Inc., Thousand Oaks. https://doi.org/10. $1002 / \mathrm{jsc} .512$

Harrison JL, Getz C (2015) Farm size and job quality: mixed-methods studies of hired farm work in California and Wisconsin. Agric Hum Values. https://doi.org/10.1007/s10460-014-9575-6

Hill EJ, Grzywacz JG, Allen S, Blanchard VL, Matz-Costa C, Shulkin S, Pitt-Catsouphes M (2008) Defining and conceptualizing workplace flexibility. Community, Work \& Family. https://doi.org/10.1080/ 13668800802024678
Hoang TG, Corbière M, Negrini A, Pham MK, Reinharz D (2013) Validation of the Karasek-Job Content Questionnaire to measure job strain in Vietnam. Psychol Rep 113(2):363-379

Liu Y, Combs JG, Ketchen DJ, Ireland RD (2007) The value of human resource management for organizational performance. Business Horizons 50(6):503-511. https://doi.org/10.1016/j.bushor.2007.07. 002

Lobley M, Potter C (2004) Agricultural change and restructuring: recent evidence from a survey of agricultural households in England. J Rural Stud 20(4):499-510

Madelrieux S, Dedieu B (2008) Qualification and assessment of work organisation in livestock farms. Animal 2:435-446. https://doi.org/ $10.1017 / \mathrm{S} 175173110700122 \mathrm{X}$

Marshall NA (2010) Understanding social resilience to climate variability in primary enterprises and industries. Glob Environ Chang 20:36-43

Marshall NA, Park S, Howden SM, Dowd AB, Jakku ES (2013) Climate change awareness is associated with enhanced adaptive capacity. Agric Syst. https://doi.org/10.1016/j.agsy.2013.01.003

Marshall N, Dowd A-M, Fleming A, Gambley C, Howden M, Jakku E, Larsen C, Marshall PA, Moon K, Park S, Thorburn PJ (2014) Agron Sustain Dev 34(3):583-591. Transformational capacity in Australian peanut farmers for better climate adaptation. https://doi. org/10.1007/s13593-013-0186-1

McKenzie F (2011) Attracting and retaining skilled and professional in remote locations of Australia. 33:353-363. https://doi.org/10.1071/ RJ11024

Mitchell JC (1983) Case and situation analysis. Sociol Rev 31:187-211. https://doi.org/10.1111/j.1467-954X.1983.tb00387.x

Moffatt J, Nettle R, Power G, Oliver D (2013) CRDC project UM1201 innovative work: cotton workforce development for sustained competitive advantage. milestone 1.2 report: review of current industry, regional and farm workforce development activities and human resource practices on farms, Cotton Research and Development Corporation, Rural Innovation Research Group. The University of Melbourne, Melbourne

Nelson DR, Adger WN, Brown K (2007) Adaptation to environmental change: contributions of a resilience framework. Annu Rev Environ Resour. https://doi.org/10.1146/annurev.energy.32.051807.090348

Nelson R, Kokic P, Crimp S, Martin P, Meinke H, Howden M, Nidumolu U (2010) The vulnerability of Australian rural communities to climate variability and change: part II - integrating impacts with adaptive capacity. Environ Sci Pol 13(1):18-27. https://doi.org/10.1016/ j.envsci.2009.09.007

Nettle R (2015) More than workforce shortages: how farm human resources management strategies will shape Australia's agricultural future. Aust Farm Policy J 12(2) Winter Quarter):15-25

NVivo qualitative data analysis Software; QSR international Pty ltd. Version 10, 2012

OECD (2017) OECD employment outlook 2017. OECD Publishing, s. https://doi.org/10.1787/empl outlook-2017-en

Palys T (2008) Purposive sampling. In L. M. Given (ed) The sage encyclopedia of qualitative research methods (Vol. 2). Sage: Los Angeles, pp 697-698

Parliament of Australia (2015) Casual employment in Australia: a quick guide, research note, Research papers 14-15. http://www.aph.gov. au/About_Parliament/Parliamentary_Departments/Parliamentary Library/pubs/rp/rp1415/Quick Guides/CasualEmploy. Sourced 5th July, 2017

Patton M (1990) Qualitative evaluation and research methods, 2nd edn. Newbury Park, CA: Sage

Pritchard B, Burch D, Lawrence GA (2007) Neither 'family' nor 'corporate' farming: Australian tomato growers as farm family entrepreneurs. J Rural Stud 23(1):75-87. https://doi.org/10.1016/j.jrurstud. 2006.04.001

Pfeffer J (1998) Six dangerous myths about pay. Harv Bus Rev 1998: 109-119 
Pfeffer J (2010) Building sustainable organizations: the human factor. Acad Manag Perspect 24(1):34-45

Porter M (1996) What is strategy? Harv Bus Rev 74, November/ December: 61-78

Ragin C (1987) The comparative method: moving beyond qualitative and quantitative strategies. University of California Press, Berkeley

Raine S, Foley J (2002) Comparing systems for cotton irrigation. The Australian Cottongrower 23(4):30-35

Rappaport A, Bancroft E, Okum L (2003) The aging workforce raises new talent management issues for employers. J Organ Excell 23(1): 55-66. https://doi.org/10.1002/npr.10101

Rasmussen L-V, Bierbaum R, Oldekop JA, Agrawal A (2017) Bridging the practitioner-researcher divide: indicators to track environmental, economic, and sociocultural sustainability of agricultural commodity production. Glob Environ Chang 42:33-46. https://doi.org/10. 1016/j.gloenvcha.2016.12.001

Robert M, Thomas A, Bergez JE (2016) Processes of adaptation in farm decision-making models. A review. Agron Sustain Dev 36(64). https://doi.org/10.1007/s13593-016-0402

Roth G, Harris G, Gillies M, Montgomery J, Wigginton D (2014) Wateruse efficiency and productivity trends in Australian irrigated cotton: a review. Crop Pasture Sci 64(12):1033-1048. https://doi.org/10. 1071/CP13315

Santhanam-Martin M, Nettle R (2014) Governing Australia's dairy farm workforce: a new terrain for negotiating rural community sustainability. Int J Sociol Agric Food 21(1):31-50

Scoones I. (1998) Sustainable rural livelihoods: a framework for analysis. IDS Working Paper 72, Institute of Development Studies

Schiere JB, Darnhofer I, Duru M (2012) Dynamics in farming systems: of changes and choices. In 'Farming systems research into the 21st century: the new dynamic'. In: Darnhofer I, Gibbon D, Dedieu B (eds) . Springer Science+Business Media, Dordrecht, pp 337-359. https://doi.org/10.1007/978-94-007-4503-2 15
Schuler RS (1992) Strategic human resource management: linking people with the needs of the business. Organ Dyn 22:19-32. https://doi.org/ 10.1177/0734371X9301300405

Schaufeli WB, Bakker AB, Salanova M (2006) The measurement of work engagement with a short questionnaire: a cross-national study. Educ Psychol Meas 66(4):701-716. https://doi.org/10.1177/ 0013164405282471

Schaufeli WB, Leiter MP, Maslach C, Jackson SE (1996) Maslach burnout inventory - general survey. In: Maslach C, Jackson SE, Leiter MP (eds) Maslach burnout inventory-test manual, 3rd edn. Consulting Psychologists Press, Palo Alto, pp 22-26

Schaufeli WB, Martinez IM, Pinto AM, Salanova M, Bakker AB (2002) Burnout and engagement in university students: a cross-national study. J Cross-Cult Psychol 33(5):464-481

Srairi MT, Ghabiyel Y (2017) Coping with work constraints in croplivestock farming systems. Ann Agric Sci 62:23-32 http://dz.doi. org/10.1016/j.aoas.2017.01.001

Stake RE (2005) Case studies. In: Denzin NK, Lincoln YS (eds) Handbook of Qualitative Research, third edn. Sage Publications, Thousand Oaks

Stanley L, Vandenberghe C, Vandenberg R, Bentein K (2013) Commitment profiles and employee turnover. J Vocat Behav 82(3):176-187. https://doi.org/10.1016/j.jvb.2013.01.011

Therond O, Duru M, Roger-Estrade J et al (2017) A new analytical framework of farming system and agriculture model diversities - a review. Agron Sust Devpt. https://doi.org/10.1007/s13593-0170429-7

Wallace M (1989) Brave new workplace: technology and work in the new economy. Work Occup 16(4):363-392

Woodhouse NP, Bennett J McL, Jensen TA (2013) Change in the cotton harvesting system: a review and implications for the John Deere 7760 Cotton Picker, NCEA Publication 1004960/13/1 National Centre for Engineering in Agriculture, University of Southern Queensland, Australia 